\title{
Pengaruh Current Ratio, Debt To Total Asset Ratio, dan Net Profit Margin Terhadap Financial Distress Pada Perusahaan Manufaktur yang Terdaftar di Bursa Efek Indonesia (BEI) Periode 2011-2014.
}

\author{
Marita Indah Sari Pratama, Myrna Sofia
}

Fakultas Ekonomi Universitas Maritim Raja Ali Haji, Tanjungpinang, Kepulauan Riau, Indonesia

\begin{abstract}
ABSTRAK: Adapun tujuan penelitian ini adalah untuk mengetahui Pengaruh Current Ratio, Debt to Total Asset Ratio, dan Net Profit Margin Terhadap Financial Distress Pada Perusahaan manufaktur yang terdaftar di Bursa Efek Indonesia periode 2011-2014. Hasil penelitian ini menunjukan bahwa secara persial Current Ratio berpengaruh signifikan terhadap Financial Distress.Sedangkan Debt to Total Asset Ratio tidak berpengaruh secara signifikan terhadap Financial Distress. Sementara untuk Net Profit Margin berpengaruh signifikan terhadap Financial Distress. Secara Simultan Current Ratio, Debt to Total Asset Ratio dan Net Profit Margin berpengaruh signifikan terhadap Financial Distres. Ini di buktikan dari uji koefisian determinan dengan nilai adjusted R2 sebesar 0,196 hal ini menunjukan bahwa 19,6 \% Financial Distress di pengaruhi oleh Current Ratio, Debt to Total Asset Ratio dan Net Profit Margin dan sisanya 80,4 \% di pengaruhi oleh variabel lain yang tidak di kaji dalam penelitian ini.
\end{abstract}

Kata Kunci : Rasio Keuangan dan Financial Distress

ABSTRACT: The purpose of this study is to determine the effect of Current Ratio, Debt to Total Asset Ratio, and Net Profit Margin to Financial Distress in manufacturing companies listed on the Indonesia Stock Exchange for the period 2011-2014. The results of this study indicate that the Persial Current Ratio has a significant effect on Financial Distress. While the Debt to Total Asset Ratio does not significantly influence the Financial Distress. While the Net Profit Margin has a significant effect on Financial Distress. Simultaneously Current Ratio, Debt to Total Asset Ratio and Net Profit Margin have a significant effect on Financial Distress. This is evidenced by the determinant coefficient of loading with the adjusted R2 value of 0.196. This shows that 19.6\% of the Financial Distress is influenced by Current Ratio, Debt to Total Asset Ratio and Net Profit Margin and the remaining $80.4 \%$ is influenced by other variables not reviewed in this study.

Keywords: Financial and Financial Distress Ratio

Email Address: maritaindah_sp@gmail.com 


\section{Pendahuluan}

Setiap perkembangan yang terjadi di dunia usaha akan membuat semakin berkembangnya pula persaingan yang terjadi terutama perusahaan yang terdaftar di Bura Efek Indonesia. Hal ini mengakibatkan adanya kemungkinan kebangkrutan yang akan terjadi pada setiap perusahaan. Kebangkrutan perusahaan di awali dengan adanya kesulitan keuangan pada perusahaan.Kebangkrutan keuangan di awali dengan adanya kesulitan keuangan pada perusahaan.Dimana kesulitan keuangan itu sendiri merupakan sebuah kondisi yang diartikan sebagai ketidakmampuan perusahaan dalam membayar kewajiban keuangannya saat jatuh tempo yang menyebabkan terjadinya kebangkrutan perusahaan.

Kesulitan yang dialami suatu perusahaan dapat diartikan sebagai ketidakmampuan perusahaan dalam memenuhi kewajibankewajibannya baik yang dalam jangka waktu pendek maupun dalam jangka waktu panjang yang nantinya akan menyebabkan kebangkrutan perusahaan. Sebuah perusahaan tidak akan mengalami kebangkrutan secara tiba-tiba, namun dalam peroses waktu yang berlangsung lama, dan itu dapat dilihat dari tanda-tanda, seperti perusahaan yang tidak dapat membayar hutangnya secara tepat waktu. Hal ini menandakan bahwa perusahaan sedang mengalami masalah likuiditas. Kesulitan likuiditas ini nantinya akan memberikan pengaruh kepada terganggunya aktivitas perusahaan ke posisi tidak berjalan secara normal yang akan mengakibatkan perusahaan mengalami financial distress. Rasio keuangan yang baik akan menunjukkan kinerja keuangan dan kondisi keuangan yang baik pula. Artinya manajemen mampu mengelola dengan baik semua hal yang terjadi diperusahaan selama satu periode tertentu, baik itu dalam hal operasional, investasi maupun pendanaan.
Selain analisis rasio keuangan yang bisa digunakan untuk memprediksi kondisi keuangan perusahaan, digunakan pula model analisis kebangkrutan untuk mengetahui kondisi kebangkrutan yang mungkin terjadi pada perusahaan.Salah satunya adalah model analisis kebangkrutan Altman Z-Score.

Berdasarkan uraian latar belakang diatas, maka penulis mencoba melakukan penelitian menggunakan metode analisis Z-Score untuk mencari tahu bagaimana kondisi Financial distress perusahaan Manufaktur yang ada di Bursa Efek Indonsesia. Adapun judul penelitian yang diajukan yaitu :"Pengaruh Current Ratio, Debt to Total Asset Ratio, dan Net Profit Margin Terhadap Financial Distress Pada Perusahaan Manufaktur yang Terdaftar di Bursa Efek Indonesia Periode 2011-2014"

Adapun perumusan masalah dalam penelitian ini adalah :

1. Apakah Current Ratio berpengaruh terhadap penilaian Financial distress pada perusahaan Manufaktur yang terdaftar di Bursa Efek Indonesia?

2. Apakah Debt to Total Aset Ratio berpengaruh terhadap penilaian Financial distress Manufaktur yang terdaftar di Bursa Efek Indonesia?

3. Apakah Net Profit Margin berpengaruh terhadap penilaian Financial distress Manufaktur yang terdaftar di Bursa Efek Indonesia?

4. Apakah Current Ratio, Debt to Total Aset Ratio,dan Net Profit Margin berpengaruh terhadap penilaian Financial distress Manufaktur yang terdaftar di Bursa Efek Indonesia?

\section{Tujuan Penelitian}

1. Untuk mengetahui apakah Current Ratio berpengaruh terhadap penilaian Financial distress pada perusahaan 
Manufaktur yang terdaftar di Bursa Efek Indonesia.

2. Untuk mengetahui apakah Debt to Total Aset Ratio berpengaruh terhadap penilaian Financial distress Manufaktur yang terdaftar di Bursa Efek Indonesia.

3. Untuk mengetahui apakah Net Profit Margin berpengaruh terhadap penilaian Financial distress Manufaktur yang terdaftar di Bursa Efek Indonesia.

4. Untuk mengetahui apakah Current Ratio, Debt to Total Aset Ratio,dan Net Profit Margin berpengaruh terhadap penilaian Financial distress Manufaktur yang terdaftar di Bursa Efek Indonesia.

\section{Kajian Pustaka}

\section{Financial Distress}

Financial distress atau kesulitan keuangan dapat di artikan sebagai ketidak mampuan perusahaan untuk membayar kewajiban keuangan pada saat jatuh tempo yang menyebabkan kebangkrutan perusahaan.Menurut Foster (1989) dalam Darsono dan Ashari (2005:101) kesulitan keuangan menunjukan adanya masalah likuiditas yang parah yang tidak dapat di pecahkan tanpa melalui penjadwalan kembali secara besar-besaran terhadap operasi dan struktur perusahaan.

\section{Permasalahan dalam Financial Distress}

Darsono dan Ashari (2005:104), menjelaskan bahwa financialdistress yang di alami oleh perusahaan harus di atasi dengan pembaruan baik struktur keuangan maupun organisasi perusahaan.

\section{Metode Altman Z-score}

Prediksi kebangkrutan usaha berfungsi untuk memberikan panduanbagi pihak-pihak tentang kinerja keuangan perusahaan apakah mengalami financial distress atau tidak di masa mendatang. Seorang profesor di New York University, Edward Altman, melakukan penelitian terhadap kinerja keuangan perusahaan yang mengalami kebangkrutan dengan kinerja keuangan perusahaan yang sehat. Hasil penelitiannya di rumuskan dalam satu rumus matematis yang di sebut dengan rumus Altman Z-score ini bisa di rumuskan sebagai berikut

\section{$\mathrm{Z}=1,2 \mathrm{WCTA}+1,4$ RETA + 3,3 EBITTA + 0,6 MVEBVL + 0,999 STA}

Diminta :

- WCTA: Working Capital to Total Asset (Modal kerja di bagi total aset)

- RETA: Retained Earning to Total Asset ( Laba ditahan dibagi total asset)

- EBITTA: Earning Before Interest and Taxes to Total asset (Laba sebelum pajak dan bunga di bagi total aset)

- MVEBVL: Market Value of Equity to Book Value of Liability (Nilai pasar ekuitas di bagi dengan nilai buku hutang)

- STA: Sales to Total Asset (Penjualan di bagi total asset )

Hasil perhitungan Z-score bisa di jelaskan dengan tabel sebagai berikut :

Tabel 2.1

Interpretasi Nilai Z-score

\begin{tabular}{|c|c|}
\hline $\begin{array}{c}\text { Nilai Z- } \\
\text { score }\end{array}$ & Interprestasi \\
\hline $\mathrm{Z}>2,99$ & $\begin{array}{c}\text { Tidak mengalami } \\
\text { Financial distress }\end{array}$ \\
\hline $1,81<\mathrm{Z}<$ & Gray area \\
2,99 & $\begin{array}{c}\text { Mengalami Financial } \\
\mathrm{Z}<1,81\end{array}$ \\
\hline distress \\
\hline
\end{tabular}

Sumber : Altman (1968) 


\section{Rasio Likuiditas}

Menurut Hery (2015:174), rasio likuiditas menggambarkan kemampuan perusahaan

untuk menyelesaikan kewajiban jangka pendeknya. Rasio-rasio ini dapat dihitung melalui sumber informasi tentang modal kerja yaitu pos-pos aktiva lancar dan utang lancar.

1. Rasio lancar (Current ratio)

Menurut Fahmi (2012:121), rasio lancar (current ratio) adalah ukuran yang umum digunakan atas solvensi jangka pendek, kemampuan suatu perusahaan memenuhi kebutuhan utang ketika jatuh tempo.

2. Rasio cepat (quick ratio)

Rasio ini menunjukan kemampuan aktiva lancar yang paling likuid mampu menutupi utang lancar.

3. Rasio kas (cash ratio)

Rasio ini menunjukan porsi jumlah kas dibandingkan dengan total aktiva lancar.
Menurut Hery (2015:188), rasio solvabilitas atau leverage ratio merupakan

rasio yang digunakan untuk mengukur sejauh mana aktiva perusahaan dibiayai dengan utang. Artinya berapa besar beban utang yang ditanggung perusahaan dibandingkan dengan aktivanya.Dalam arti luas dikatakan bahwa rasio solvabilitas digunakan untuk mengukur kemampuan untuk membayar seluruh kewajibannya, baik jangka pendek maupun jangka panjang apabila perusahaan dibubarkan (dilikuidasi).

\section{Rasio Rentabilitas}

Menurut Hery (2015:226), rasio profitabilitas merupakan rasio untuk menilai kemampuan perusahaan dalam mencari keuntungan. Rasio ini juga memberikan ukuran tingkat efektifitas manajemen suatu perusahaan. Hal ini di tunjukan oleh laba yang di hasilkan dari penjualan dan pendapatan investasi.

\section{Rasio Solvabilitas}




\section{KERANGKA PEMIKIRAN}

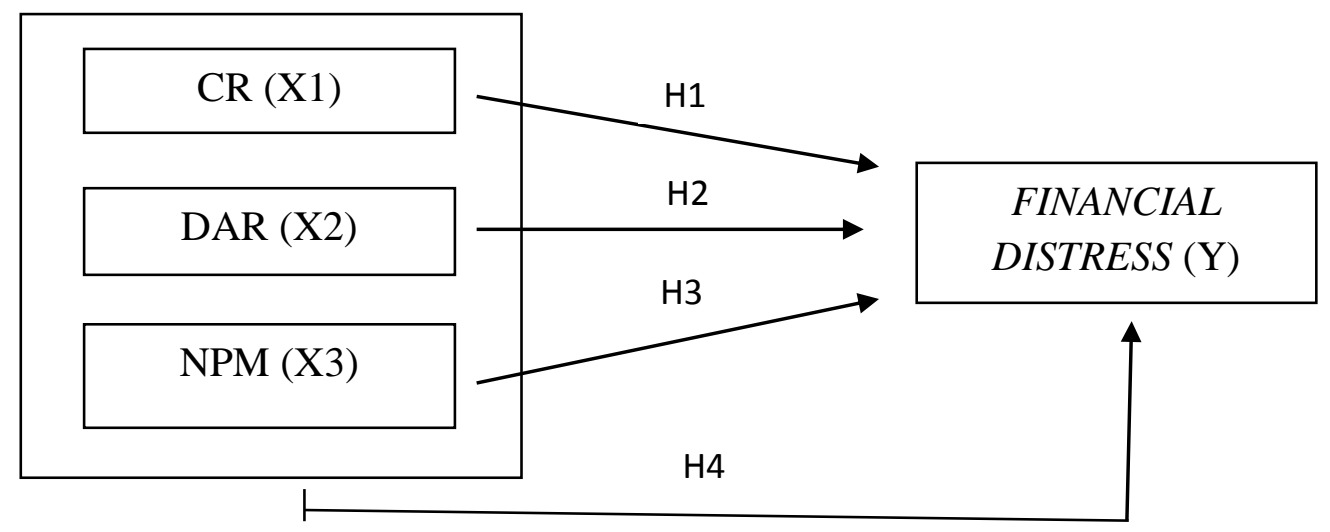

Gambar 1

Kerangka Pemikiran

\section{Hipotesis}

Adapun hipotesis dalam penelitian ini adalah sebagai berikut:

$\mathrm{H}_{1:} \quad$ Diduga Current Ratio berpengaruh signifikan terhadap Financial Distress pada perusahaan Manufaktur yang terdaftar di Bursa Efek Indonesia.

$\mathrm{H}_{2}$ : Diduga Debt to Total Aset Ratio berpengaruh signifikan terhadap Financial Distress pada perusahaan Manufaktur yang terdaftar di Bursa Efek Indonesia.
$\mathrm{H}_{3}$ : $\quad$ Diduga Net Profit Margin berpengaruh signifikan terhadap Financial Distress pada perusahaan Manufaktur yang terdaftar di Bursa Efek Indonesia.

$\mathrm{H}_{4}$ : Diduga Current Ratio,Debt to Total Aset Ratio dan Net Profit Margin berpengaruh signifikan terhadap Financial Distress pada perusahaan Manufaktur yang terdaftar di Bursa Efek Indonesia

$$
\text { Z=1,2 WCTA + 1,4 RETA + 3,3 EBITTA + 0,6 MVEBVL + 0,999 }
$$

\section{Metodologi Penelitian}

\section{Objek dan Ruang Lingkup Penelitian}

Objek dalam penelitian ini terdiri dari variabel dependen dan independen. Variabel independen adalah Current Ratio,Debt to Total Aaset Ratio, dan Net Profit Margin. Variabel dependen adalah Financial Distress .Penelitian ini di lakukan pada laporan keuangan tahunan perusahaan Manufaktur yang terdaftar di Bursa Efek Indonesia periode 2011-2014. Dan Financial Distress sebagai variabel terikat.

\section{Operasionalisasi Variabel Penelitian Variabel Dependen}

Financial distress yang di proksikan dengan Z"Score (Altman).

Z"Score dirumuskan sebagai berikut :

Keterangan:

- WCTA : Working Capital to Total Asset (Modal kerja dibagi total asset)

- RETA : Retained earning to Total Asset ( Laba ditahan dibagi total asset)

- EBITTA : Earnimg Before Interest and Taxes to Total Asset(Laba sebelum pajak dan bunga di bagi total asset) 


\begin{tabular}{|l|c|c|c|c|c|}
\hline \multicolumn{7}{|c|}{ Descriptive Statistics } \\
\hline & $\mathrm{N}$ & Min & Max & Mean & $\begin{array}{c}\text { Std. } \\
\text { Deviation }\end{array}$ \\
\hline CR & 187 &, 2112 & 5,7733 & 2,157756 & 1,1742204 \\
\hline DAR & 187 &, 0015 &, 8375 &, 386803 &, 2006626 \\
\hline NPM & 187 &, 0005 &, 2825 &, 083496 &, 0614691 \\
\hline FD & 187 &,- 3940 & 4,8572 & 2,059098 & 1,0459553 \\
\hline Valid N & 187 & & & & \\
(listwise) & & & & & \\
\hline
\end{tabular}

- MVEBVL : Market Value of Equity to Book Value of Liability

- (Nilai pasar ekuitas dibagi dengan nilai buku hutang)

- STA : Sales to Total Asset (Penjualan dibagi total asset)

\section{Variabel Independen}

Variabel bebas dalam penelitian ini adalah Current Ratio, Debt to Total Aset Ratio dan Net Profit Margin.

\section{Rasio Likuiditas}

\section{Rasio Solvabilitas}

$$
\text { RasioLancar }=\frac{\text { Asset lancar }}{\text { utang lancar }}
$$

$$
D A R=\frac{\text { total Debt }}{\text { Total Asset }}
$$

\section{Rasio Rentabilitas}

$$
\mathrm{NPM}=\frac{\text { lababersih }}{\text { penjualanbersih }}
$$

\section{Populasi}

Popolasi dalam penelitian ini adalah perusahaan Manufaktur yang terdaftar di Bursa Efek Indonesia dalam kurun periode 20112014 yang berjumlah 144 perusahaan.

\section{Sampel}

Menurut Efferin (2008:85), sampel adalah cuplikan atau bagian dari populasi .sampel dalam penelitian ini adalah perusahaan manufaktur yang terdaftar di BEI.Sampel dalam penelitian ini di tentukan dengan menggunakan teknik purposive sampling.

\section{Hasil Penelitian dan Pembahasan}

\section{Tabel 1}

\section{Descriptive Statistics}

Sumber: data diolah, 2017

Berdasarkan hasil pengujian statistik deskriptif diatas dapat dilihat bahwa penelitian ini memiliki 187 data pengamatan yang merupakan data keseluruhan dari tahun 2011 sampai dengan tahun 2014. penelitian ini memiliki 187 data pengamatan yang merupakan data keseluruhan dari tahun 2011 sampai dengan tahun 2014.

Tabel 7

Uji Hipotesis (Uji t)

\begin{tabular}{|c|r|r|r|c|c|}
\hline \multicolumn{7}{|c|}{ Model Summary } \\
\hline $\begin{array}{c}\text { M } \\
\text { o }\end{array}$ & R & $\begin{array}{c}\text { R } \\
\text { Squar } \\
\text { e }\end{array}$ & $\begin{array}{c}\text { Adjuste } \\
\text { d R } \\
\text { Square }\end{array}$ & $\begin{array}{c}\text { Std. } \\
\text { Error of } \\
\text { the } \\
\text { Estimate }\end{array}$ & $\begin{array}{c}\text { Durbi } \\
\text { n- } \\
\text { Watso } \\
\mathrm{n}\end{array}$ \\
\hline 1 & $\begin{array}{r}457 \\
\text { a }\end{array}$ &, 209 &, 196 &, 9380281 & 2,237 \\
\hline
\end{tabular}

Sumber: data diolah, 2017 
Berdasarkan tabel diatas, dapat dilihat bahwa hipotesis pertama yaitu rasio CR berpengaruh signifikan terhadap tingkat kebangkrutan perusahaan pada perusahaan manufaktur di BEI tahun 2011 sampai dengan 2014 menunjukkan nilai thitung sebesar 4,760 lebih besar dari t tabelnya yakni sebesar 1,972731. Dengan demikian hipotesis pertama diterima.

Hipotesis kedua dalam penelitian ini yaitu rasio DAR berpengaruh signifikan terhadap tingkat kebangkrutan perusahaan sektor industri dasar dan kimia tahun 2011 sampai dengan 2014 di Bursa Efek Indonesia . menunjukkan hasil dari t hitung sebesar 1,228 lebih kecil dari t tabel yakni 1,972731.

Dengan demikian hipotesis kedua ditolak.

Untuk hipotesis ketiga dalam penelitian ini yaitu rasio NPM berpengaruh signifikan terhadap tingkat kebangkrutan perusahaan berdasarkan tabel di atas menunjukkan hasil bahwa t hitung yang dimiliki adalah sebesar 3,582 lebih besar dari tabel dalam penelitian ini yakni sebesar 1,972731. Dengan demikian hipotesis ketiga diterima.

Tabel 8

Hasil Uji F

\begin{tabular}{|c|c|c|c|c|c|c|}
\hline \multicolumn{7}{|c|}{ ANOVA $^{\mathrm{a}}$} \\
\hline & Model & $\begin{array}{c}\text { Sum of } \\
\text { Squares }\end{array}$ & Df & $\begin{array}{l}\text { Mean } \\
\text { Square }\end{array}$ & $\mathrm{F}$ & Sig. \\
\hline \multirow{3}{*}{1} & Regression & 42,467 & 3 & 14,156 & 16,088 &, $000^{\mathrm{b}}$ \\
\hline & Residual & 161,021 & 183 & ,880 & & \\
\hline & Total & 203,488 & 186 & & & \\
\hline \multicolumn{7}{|c|}{ a. Dependent Variable: FD } \\
\hline \multicolumn{7}{|c|}{ b. Predictors: (Constant), NPM, CR, DAR } \\
\hline
\end{tabular}

Dari tabel penelitian diatas menunjukkan bahwa nilai f hitung sebesar 16,088 dengan nilai f tabel sebesar 2,65 dan nilai signifikansi sebesar 0,000 dengan tingkat signifikansi yang digunakan adalah sebesar $0.05(5 \%)$. Nilai $\mathrm{f}$ hitung yang lebih besar dari pada nilai $\mathrm{f}$ tabel serta tingkat signifikansi yang lebih kecil dari 0.05 menunjukkan bahwa model penelitian dengan variabel independen current ratio, debt to total asset ratio, dan net profit margin secara bersama-sama mempengaruhi variabel dependen yaitu tingkat kebangkrutan perusahaan.

\section{Uji Adjusted $\mathbf{R}_{2}$}

Tabel 9

Koefisien Determinasi 


\begin{tabular}{|l|c|r|r|r|l|}
\hline \multicolumn{7}{|c|}{ Model Summary $^{\text {b }}$} \\
\hline del & R & $\begin{array}{c}\text { R } \\
\text { Square }\end{array}$ & $\begin{array}{c}\text { Adjusted } \\
\text { R Square }\end{array}$ & $\begin{array}{c}\text { Std. Error } \\
\text { of the } \\
\text { Estimate }\end{array}$ & $\begin{array}{c}\text { Durbin- } \\
\text { Watson }\end{array}$ \\
\hline 1 &, $457^{\mathrm{a}}$ &, 209 &, 196 &, 9380281 & 2,237 \\
\hline \multicolumn{7}{|l|}{ a. Predictors: (Constant), NPM, CR, DAR } \\
\hline
\end{tabular}

Sumber: data diolah, 2017

Dari tabel diatas dapat di lihat bahwa nilai koefisiensi determinasi (Adjusted RSquare)adalah sebesar 0,196 atau 19,6\%. Hal ini menunjukan bahwa 19,6 \% Financial distress dapat dijelaskan oleh CR,DAR,NPM. Dan sisanya 80,4\% dapat dipengaruhi atau di jelaskan oleh variabel lain diluar dari variabel penelitian ini.

\section{Kesimpulan}

Berdasarkan hasil analisis dan pengujian hipotesis, yang telah dilakukan, dapat ditarik kesimpulan sebagai berikut :

1. Berdasarkan hasil pengujian dengan menggunakan regresi linier berganda menunjukkan bahwa Current ratio berpengaruh signifikan terhadap Kondisi Financial distress perusahaan manufaktur yang terdaftar di BEI (Bursa Efek Indonesia) tahun 2011-2014.

2. Berdasarkan hasil pengujian dengan menggunakan regresi linier berganda menunjukkan bahwa debt to total asset ratio tidak berpengaruh signifikan terhadap Kondisi Financial distress perusahaan manufaktur yang terdaftar di
BEI (Bursa Efek Indonesia) tahun 20112014.

3. Berdasarkan hasil pengujian dengan menggunakan regresi linier berganda menunjukkan bahwa net profit margin berpengaruh signifikan terhadap Kondisi Financial distress perusahaan manufaktur yang terdaftar di BEI (Bursa Efek Indonesia) tahun 2011-2014.

4. Hasil uji hipotesis dengan Uji Simultan (Uji F), menunjukan current ratio, debt to total asset ratio, dan net profit margin secara bersama-sama berpengaruh signifikan terhadap kondisi Financial Distress perusahaan sektor industri dasar dan kimia yang terdaftar diBursa Efek Indonesia (BEI) tahun 2011-2014.

\section{Saran}

Adapun saran yang dapat direkomendasikan untuk penelitian selanjutnya berdasarkan keterbatasan yang ada dalam penelitian ini adalah sebagai berikut:

1. Berdasarkan hasil penelitian yang dilakukan, peneliti selanjutnya dapat menambah variabel bebas berupa rasio keuangan yang

dapat dijadikan sebagai faktor yang dapat mempengaruhi tingkat kebangkrutan perusahaan.

2. Peneliti selanjutnya juga diharapkan dapat menambah sampel penelitian atau mengganti dengan perusahaan lain mengingat penelitian ini hanya menggunakan perusahaan manufaktur. 


\section{Daftar Pustaka}

Altman, E. (1968). The Journal Of Finance. Financial Ratios, Discriminant Analysis and the of Corporate .

Arif, M. H. (2013). Prediksi Financial Distress Perusahaan Manufaktur di Indonesia.Semarang : Fakultas Ekonomika dan Bisnis Universitas Diponegoro.

Artika, \& Dkk. (2011). Pengaruh Beberapa Rasio Keuangan Terhadap Prediksi Kondisi Financial Distress. Fakultas Ilmu Administrasi Universitas Brawijaya Malang .

Darsono, \& Ashari. (2005). Pedoman Praktis Memahami Laporan Keuangan. Yogyakarta: ANDI OFFSET.

Efferin, S. (2008). Metode Penelitian Akuntansi. Yokyakarta: Graha Ilmu.

Fahmi, i. (2012). Analisis Laporan Keuangan. Bandung: ALFABETA.

Ghozali, I. (2013). Aplikasi Analisis Multivariate Dengan Program IBM SPSS 21. Semarang: Badan Penerbit Universitas Diponegoro.

Haq, S., Arfan, M., \& Siswar, D. (2013). Analisis Rasio Keuangan Dalam Memprediksi Financial Distress (Studi Pada Perusahaan Yang Terdaftar Di BEI ). Jurnal Akuntansi Pasca Sarjana Universitas Syah Kuala .

Hery. (2012). Analisis Laporan Keuangan. yokyakarta: CAPS (Center for Academic Publishing Service).
Julianty, R. (2008). Analisis Laporan Keuangan konsep dan Aplikasi edisi kedua . Yogyakarta: STIM YKPN.

Liana, Deny, \& Sutrisno. (2014). Analisis Rasio Keuangan Untuk memprediksi Kondisi Financial Distress Perusahaan Manufaktur. Jurnal Studi Manajemen dan Bisnis Vol.1 No.2, 52-62.

Luciana. (2009). Analisis Rasio Keuangan Untuk Memprediksi Kondisi Financial Distress Perusahaan Manufaktur Yang Terdaftar di Bursa Efek Jakarta . Fakultas Ekonomi Universitas Indonesia Esa Unggul Jakarta .

Okta, K. (2015). Pengaruh Good Corporate Governant Dan rasio Keuangan Terhadap Financial Distress. Jurnal Ilmu dan Riset Akuntansi Vol 4 No 10 .

Putra, A. W. (2015). Pengaruh Rasio Keuangan Dalam Memprediksi Kondisi Financial Distress Perusahaan Manufaktur Di BEI . Sekolah Tinggi Ilmu Ekonomi Perbanas Surabaya .

Rachmawati, \& Shantri, A. (2011). Pengaruh Aktiva Tetap Tak Berwujud Terhadap Financial Distress pada Perusahaan Manufaktur yang terdaftar di Bursa Efek Indonesia Periode 2007-2010. Jurnal Studi Akuntansi .

Wahyu, L. W. (2014). Pengaruh Current Ratio,Debt to Equaty Ratio,dan Return On Equity Untuk Memperediksikan Kondisi Financial Distress. Alumni Universitas Stikubank Semarang .

Widarjo, W., \& Setiawan, D. (2009). Pengaruh Rasio Keuangan Terhadap Financial Distress Perusahaan Automotif. Jurnal 
Bisnis dan Akuntansi Vol.11, No.2, Agustus 2009 .

Yuniarti. (2012). Pengaruh Rasio Keuangan Terhadap Prediksi Financial Distress PerusahaanIndustri Dasar Dan Kimia Yang Terdaftar Di Bursa efek
Indonesia. Jurnal Ekonomi Manajemen Vol 6 No.2 Juli .

http://www.idx.co.id

www.financial.yahoo.com 